\title{
PENGGUNAAN MEDIA KOLASE DALAM MENGEMBANGKAN KETERAMPILAN MOTORIK HALUS ANAK USIA 5-6 TAHUN
}

\author{
Ani Oktarina ${ }^{1}$, Sa'idy $^{2}$, Wardah Angraini ${ }^{3}$, Beti Susilawati ${ }^{4}$ \\ ${ }^{1,3}$ Universitas Islam Negeri Sunan Kalijaga Yogyakarta, Indonesia \\ ${ }^{2}$ Universitas Islam Negeri Raden Intan lampung, Indonesia \\ ${ }^{4}$ AMIK Dian Cipta Cendikia Bandar Lampung, Indonesia \\ Oktarinamuhyins21@gmail.com
}

\begin{abstract}
The low motor skills of children are one of the reasons this research was conducted, as well as wanting to know how the teacher's efforts to improve the fine motor skills of children aged 5- 6 years by wearing collage media. This research methodology uses descriptive analysis with a qualitative approach, linking one class teacher for children aged 5- 6 years. Information collected through interviews, observation and documentation. Information is analyzed qualitatively using information reduction methods, information presentation and drawing conclusions. The results of this research show that the methods tried in this collage activity have been carried out well and can improve the fine motor skills of children aged 5- 6 years, but some have not yet grown. This is a part that becomes a benchmark for comparison from other previous studies, where the results of research that are often intertwined is that with the use of this collage media, the fine motor skills of children aged 5-6 years can grow optimally. After this research is conducted, it is necessary to have in-depth teaching intensity for motoric development of children in the school.
\end{abstract}

Keywords: early childhood, skills, collage, fine motor skills

\begin{abstract}
Abstrak
Rendahnya kemampuan motorik anak menjadi salah satu alasan penelitian ini dilakukan, serta ingin mengetahui bagaimana upaya guru dalam meningkatkan kemampuan motorik halus anak umur 5- 6 tahun dengan mengenakan media kolase. Tata cara riset ini memakai analisis deskriptif dengan pendekatan kualitatif, yang mengaitkan satu orang guru kelas anak umur 5- 6 tahun. Informasi yang dikumpulkan lewat wawancara, observasi serta dokumentasi. Informasi dianalisis secara kualitatif memakai metode reduksi informasi, penyajian informasi serta penarikan kesimpulan. Hasil riset ini menampilkan kalau, cara- cara yang dicoba dalam aktivitas kolase tersebut sudah terlaksana dengan baik serta bisa meningkatkan keahlian motorik halus anak umur 5- 6 tahun, hendak namun masih terdapat yang belum tumbuh. Ini merupakan bagian yang jadi tolak ukur perbandingan dari penelitian- penelitian terdahulu yang lain, dimana hasil riset yang kerap terjalin ialah dengan terdapatnya pemakaian media kolase ini, motorik halus anak umur 5-6 tahun telah bisa tumbuh dengan maksimal. Setelah penelitian ini dilakukan, perlu adanya intensitas pengajaran yang mendalam untuk perkembangan motorik anak di sekolah tersebut.
\end{abstract}

Kata Kunci: anak usia dini, keterampilan, kolase, motorik halus 


\section{PENDAHULUAN}

Pendidikan anak usia dini ialah sebuah wahana Pendidikan untuk membangun bentuk perkembangan suatu dasar pengetahuan sikap dan keterampilan anak. Pendidikan anak usia dini ialah suatu proses keberhasilan. Karena, anak diminta memiliki potensipotensi yang dapat berkembang pada masa Golden Age ataupun masa keemasannya (Nana Sudjana, 2016). Menurut Sujiono, anak usia dini adalah gambaran seseorang yang mengalami proses perkembangan yang cepat dan mendasar dalam kehidupan berikutnya. Kemudian, Yusuf dan Sughandi berpendapat bahwa masa kanak-kanak benar-benar masa depan atau masa pertumbuhan yang menentukan masa depan (Azizah, 2017).

Anak usia dini cenderung memiliki karakteristik yang khas dan berbeda-beda, mereka selalu antusias dan selalu ingin tau terhadap apa yang dilihat, dirasakan, dan didengar, mereka selalu aktif dan suka belajar dan mengeksplorasi. Anak dapat termotivasi dalam perkembangan nya melalui belajar sambal bermain (Ahmad Susanto, 2015). Pembelajaran yang sesuai dengan anak ialah pembelajaran yang sesuai dengan minatnya. Anak akan berkembang melalui tahapan perkembangannya karena mereka ialah individu yang sangat unik (Ramdhania, 2012).

Karakteristik masa kanak-kanak adalah sebagai berikut. (1) Tingginya rasa ingin tahu anak (2) Kepribadian unik (3) Suka berimajinasi dan berfantasi (4) Waktu yang potensial untuk anak (5) Sikap egois (6) Konsentrasi lemah (7) bagian dari keberadaan sosial (Wulandari, 2015). Keterampilan motorik halus adalah kemampuan anak dalam menunjukkan dan mengendalikan gerakan otot yang indah dalam bentuk tangan, koordinasi jari, kehalusan dan presisi (Uyu Wahyudin dan Mubiar Agustin, 2001). Menurut Sumantri, motorik halus adalah organisasi dari sekelompok otot kecil, seperti jari dan tangan, yang kerap membentuk presisi dan koordinasi di tangan. Keterampilan dan penggunaan ini dilakukan menggunakan alat untuk bekerja dengan objek (Sumantri, 2005).

Motorik halus ialah sebuah Gerakan yang dilakukan oleh bagian-bagian tubuh tertentu dan hanya melibatkan sebagian kecil otot tubuh. Gerak pada motorik halus merupakan hasil dari belajar dan latihan dengan memperhatikan kematangan fungsi organ motoriknya. Gerakan yang dilakukan tidak memerlukan tenaga, akan tetapi perlu adanya koordinasi antara mata dan tangan (Suyadi, 2010). Dari penjelasan diatas, dapat 
disimpulkan bahwasanya motorik halus ialah suatu gerak yang dilakukan pada otot-otot kecil, seperti gerakan pada jari-jemari tangan dan gerakanan pada pergelangan tangan yang tepat. Oleh sebab itu, gerakan ini lebih membutuhkan koordinasi antara mata dan tangan yang cermat dibanding tenaga. Semakin anak dapat berkreasi dengan baik, maka semakin baik pula gerak motorik halusnya. Perkembangan motorik halus merupakan perkembangan gerakan anak yang menggunakan otot kecil atau sebagian anggota tubuh tertentu yang dipengaruhi oleh kesempatan anak untuk belajar dan berlatih (Pura, 2019).

Motorik halus bagi anak usia dini merupakan suatu hal yang sangat penting bagi perkembangan anak. Anak membutuhkan tangan untuk belajar dengan baik untuk keterampilan hidup, mereka belajar mengkoordinasikan mata dan gerakan tangan (Indraswari, 2012). Menurut Misyanti, motorik halus berpengaruh pada kesiapan anak dalam menulis untuk kejenjang Pendidikan yang lebih tinggi (Misiyanti et al., 2018). Gerakan motorik halus adalah apabila gerakan yang hanya otot-otot kecil, seperti keterampilan jari-jemari tangan dan pergelangan tangan yang tepat (Altenmüller, 2003). Pada anak yang sudah baik kematangan motorik halusnya biasanya cenderung menunjukkan aktivitas kemandirian karena tangannya sudah dapat terampil untuk melakukan berbagai hal (Wandi \& Mayar, 2019). Tujuan dari keterampilan motorik halus yaitu ; a. mampu mengfungsikan otot-otot kecil seperti gerakan jari tangan, b. mampu mengkoordinasikan kecepatan tangan dan mata, c. mampu menegendalikan emosi (Cllaudia et al., 2018).

Keterampilan motorik halus ialah suatu pengorganisasian dengan sekelompok otot kecil, seperti jari dan tangan, yang biasanya membutuhkan koordinasi dan akurasi visual dan keterampilan (Indraswari, 2012). Termasuk menggunakan alat untuk bekerja dan benda kecil, atau mengendalikan mesin, seperti menjahit, mengetik, dan sebagainya (Sumantri, 2005). Seperti pada umumnya bahwasanya memerlukan jangka waktu yang lama dalam proses mencapai keterampilan motorik halus pada anak. Maka sangat dibutuhkan keterangan dalam kegiatan mengembangkan keterampilan motorik halus anak tersebut. Perkembangan keterampilan motorik halus anak berbeda-beda, tergantung pada kematangan anak itu sendiri, ada yang berjalan dengan cepat begitu juga sebaliknya (Azizah, 2017). 
Ahmad Susanto berpendapat bahwa, keterampilan motorik halus ialah suatu kegiatan yang menggunakan otot halus pada kaki dan tangannya. Motorik halus ialah suatu gerak yang hanya melibatkan bagian-bagian tubuh tertentu dan tidak memerlukan tenaga (Ahmad Susanto, 2015). Teori Herlock menyatakan bahwa keterampilan motorik tidak akan berkembang dalam kedewasaan, tetapi dalam keterampilan yang perlu dipelajari. Kondisi penting untuk belajar keterampilan motorik halus dipengaruhi oleh beberapa aspek, yaitu: (1) kemauan untuk belajar; (2) peluang pelatihan; (3) peluang praktik; (4) model yang baik; (5) orientasi; (6) motivasi; (7) setiap keterampilan harus dipelajari secara individual; (8) keterampilan harus dipelajari satu per satu (Ayu Husniyatul Laily, 2014).

Pertumbuhan fisik pada anak diharapkan terjadi secara optimal, karena akan mempengaruhi perilaku anak dalam sehari-harinya. Apabila mengalami hambatan pada anak yang tubuhnya terlalu besar atau malas gerak, maka anak akan kesulitan dalam mengikuti permainan yang dilakukan oleh teman sebayanya. Maka dari itu, secara tidak langsung sebuah pertumbuhan dan perkembangan keterampilan fisik/motorik anak akan mempengaruhi cara pandang anak tersebut terhadap dirinya maupun orang lain. Oleh karena itu, dapat disimpulkan bahwa keterampilan motorik yang mencakup gerak yang dilakukan pada anak saat bermain sangat diperlukan (Bambang Sujiono, 2012).

Standar kompetensi kurikulum TK menyatakan bahwa tujuan pendidikan di taman kanak-kanak adalah untuk mempromosikan pengembangan berbagai kemampuan anakanak, psikologis dan fisik, yang meliputi nilai-nilai moral dan agama, emosional, emosional, kognitif, linguistik, fisik. Motor, kemandirian dan seni. Untuk mengembangkan keterampilan dasar anak, berdasarkan keterampilan fisik atau motoriknya, guru taman kanak-kanak akan membantu mengembangkan keterampilan motorik anak dalam hal sosialisasi dan pelatihan gerakan motorik kasar dan halus anak, meningkatkan kemampuan untuk mengendalikan, mengendalikan gerakan tubuh dan koordinasi serta keterampilan tubuh dengan cara yang sehat. hidup sehingga ia dapat mempertahankan pertumbuhan fisik yang kuat, sehat dan terampil (Bambang Sujiono, 2012). Anak mulai menggenggam dan melepaskan suatu objek, serta memegang krayon dengan jarinya ialah pada usia 3-4 tahun. Sedangkan anak mulai peningkatan dan penguasaan motorik halus dengan memegang benda-benda seperti gunting, pensil, dan menempel pada usia 5-6 tahun. Pada usia inni, anak juga sudah mampu menjiplak geometri, memotong dengan gunting, mencetak dan 
juga kegiatan yang mengacu pada keterampilan tangannya yang semakin baik (Yuliani Nuraini Sujiono, 2013).

Maka alat belajar adalah insentif yang tepat untuk pengembangan keterampilan motorik anak sehingga mereka dapat berkembang dengan sempurna . Kata media berasal dari bahasa latin, yang secara harfiah berarti, tengah, perantara dan memperkenalkan (Paizaluddin, 2016). Media adalah pengelola pesan atau manajemen pesan pengirim untuk pesan tersebut. Media secara keseluruhan adalah orang, bahan, dan peristiwa yang menciptakan kondisi bagi siswa untuk mendapatkan pengetahuan, keterampilan, atau sikap. Dalam hal ini, guru, siswa, buku, teks dan lingkungan sekolah adalah sarana komunikasi. Media ialah pembawa pesan dari komunikator menuju komunikan yang merupakan sebagai salah satu komponen komunikasi (Arif S. Sadirman dkk, 1984). Berdasarkan uraian di atas dapat disimpulkan bahwasanya media ialah sebuah komponen yang digunakan untuk menyalurkan pesan dari pengirim ke penerima. Dengan kata lain media pembelajaran adalah alat bantu proses dalam belajar mengajar.

Kolase adalah seni menempelkan gambar atau pola menggunakan berbagai bahan, seperti kertas dan kain, dilem ke latar belakang. Sementara itu, menurut Nicholson, kolase adalah gambar yang terbuat dari potongan kertas atau bahan yang dilampirkan lainnya. Berdasarkan pendapat di atas, dapat disimpulkan bahwa kolase adalah proses menggabungkan beberapa potong bahan dalam bentuk kertas atau bahan lain yang menempel pada permukaan kertas untuk membentuk gambar. Menurut Sumanto, kolase dalam Bahasa inggris "Collage" berasal dari kata "Coller" yang artinya merekat. Sedangkan secara istilah kolase ialah sebuah kreasi aplikasi yang dibuat dengan menggabungkan tekhnik melukis dengan menempelkan bahan-bahan tertentu (Effi Kumala sari, 2018).

Kolase adalah karya seni baru dengan teknik merekatkan berbagai elemen menjadi satu bingkai. Jadi, kolase adalah karya seni yang dibuat dengan merekatkan bahan apa saja menjadi komposisi yang serasi, sehingga menjadi satu karya (Syakir Muharrar dan Sri Verayanti, 2013). Sehingga beberapa pendapat diatas mengarah pada kesimpulan bahwa kolase adalah kegiatan meletakkan berbagai macam bahan baik berupa kertas maupun bahan lain yang direkatkan pada permukaan kertas untuk membentuk gambar. Kolase memiliki beberapa manfaat yaitu: (1) melatih motorik halus pada anak; (2) meningkatkan 
kreativitas anak; (3) mengajar konsentrasi anak; (4) pengenalan warna; (5) pengenalan bentuk pada anak; (6) membiasakan anak-anak dengan spesies dan berbagai bahan; (7) menanamkan kualitas materi pada anak; (8) mengajari anak ketekunan; (9) mengajar anakanak keterampilan ruang; (10) mengajar anak untuk memecahkan masalah; (11) ajari anak untuk percaya diri (Ramdhania, 2012).

Fungsi kolase dalam tumbuh kembang anak adalah melatih keterampilan motorik halus, mengembangkan kreativitas, mengenal konsep warna, mengenal pola dan bentuk, serta melatih ketekunan dan kepercayaan diri. Kemendiknas menambahkan fungsi kolase adalah untuk mengembangkan imajinasi, mengembangkan kreativitas, tepat dan sabar, membuat sesuatu dengan teknik kolase. (Depdikbud, 2013). Langkah-langkah guru dalam pengembangan keterampilan motorik halus dengan bantuan kolase: (1) cetak biru selesai; (2) penyediaan alat dan bahan; (3) menjelaskan dan memperkenalkan nama alat yang digunakan untuk memperkuat keterampilan dan bagaimana alat tersebut digunakan; (4) membimbing anak-anak dalam proses menempelkan bahan yang disediakan untuk menggambar; (5) jelaskan posisi yang benar selama pengeleman sesuai dengan bentuk gambar dan perlihatkan agar pengeleman tidak melewati garis; (6) menilai hasil akhir siswa setelah kelas (Yutika Oktavia Ardila, 2017).

Berikut adalah kelebihan dari menggunakan bahan pada kegiatan kolase dalam pembelajaran : (1) bahan yang digunakan mudah didapatkan; (2) dapat berperan sebagai bentuk hiburan bagi anak; (3) memiliki peran atau fungus sebgai alat atau media mencapai sasaran Pendidikan secara umum; (4) dapat mengembangkan kreativitas siswa dan pembelajaran tidak menjadi membosankan; (5) siswa dapat berperan aktif dalam kegiatan pembelajaran dan dapat menghasilkan anak didik yang memiliki keterampilan, kreatif, inovatif; (6) adanya prinsip kepraktisan (7) dapat melatih konsentrasi; (8) melatih memecahkan masalah; (9) siswa dapat meningkatkan kepercayaan diri; (10) dapat transfer belajar sesuai tujuan pembelajaran yang ingin dicapai (Rully ramdansyah, 2010). Kegiatan mengeksplor kegunan baru dari macam-macam kertas, koordinasi antara mata dan tangan, belajar mengenai konsep desain dari pola, menempatkan bentuk dan ukuran, serta mengembangkan kreativitas adalah kegiatan yang baik dilakukan pra sekolah agar dapat menegmbangkan keterampilan motorik halusnya (Mary Mayesky, 2011). 
Menempel dalam bahasa prancisnya adalah Collage, yang berarti kolase. Menurut istilah, kolase ialah menempelkan bahan bahan tertentu menggunakan tekhnik lukis (lukis tangan) menjadi suatu kreasi aplikasi (Sumanto, 2006). Kolase adalah kegiatan yang menarik untuk diberikan pada anak karena anak dapat merekatkan sesuatu sesuka mereka. Kolase ialah suatu penyusunan bahan pada kertas lembar, bahan bertekstur yang menarik lainnya, bias dia atau tiga dimensi (Moeslichaton, 2004). Hal yang dianggap penting dalam hidup adalah pendidikan. Kita dapat lebih dihormati untuk karir yang baik, dipandang terhormat, dan kita dapat berperilaku sesuai dengan standar yang berlaku seiring dengan perubahan zaman dalam dunia pendidikan, sehingga pola pikir pendidik telah banyak berubah dari pemikiran konvensional menjadi pemikiran yang lebih modern. (Romlah, 2017).

Menurut undang-undang tentang sistem pendidikan nasional, pendidikan adalah upaya sadar dan terencana untuk menciptakan suasana belajar dan proses pembelajaran agar peserta didik secara aktif mengembangkan potensi kekuatan spiritual keagamaan, pengendalian diri, masyarakat, bangsa, dan negara. Pada anak usia dini, beberapa aspek perkembangan perlu didorong, salah satunya adalah pengembangan keterampilan motorik halus. Anak yang belum memiliki kemampuan motorik halus memerlukan banyak stimulasi agar tidak mengalami kesulitan dalam mengkoordinasikan gerakan tangan dan jari. (Kartikasari, 2013).

Keterampilan motorik halus melibatkan pengorganisasian penggunaan sekelompok otot kecil seperti jari dan tangan, yang seringkali memerlukan koordinasi mata yang cermat, keterampilan yang mencakup penggunaan alat kerja dan benda kecil, atau mesin operasi seperti mengetik, menjahit, teka-teki, menulis, membuat kolase, dll. kegiatan lainnya (Mulyasa, 2014). Perkembangan motorik halus dipengaruhi oleh berbagai faktor, antara lain kemauan belajar, kesempatan belajar, kesempatan berlatih, model yang baik, bimbingan motivasi, dan tindakan individu. Masa perkembangan anak usia dini adalah seseorang yang sedang mengalami proses perkembangan yang pesat, sekaligus proses perkembangan mental dalam kehidupan anak di masa depan. Ada beberapa aspek perkembangan dalam perkembangan yaitu agama, sosial, kognitif, motorik, artistik dan kebahasaan. Dari aspek tersebut peneliti tertarik untuk mempelajari perkembangan motorik halus pada anak usia dini. Keterampilan motorik halus disini merupakan bentuk koordinasi, 
ketangkasan, dan ketangkasan dalam menggunakan jari tangan. (Uyu Wahyudin dan Mubiar Agustin, 2001).

Media dalam pendidikan merupakan stimulus yang tepat untuk perkembangan keterampilan motorik halus pada anak agar dapat berkembang secara ideal. Collage bonding adalah penataan bahan pada lembaran kertas datar, kain, dan bahan terstruktur menarik lainnya. Bisa 2D atau 3D. Pengeleman ini menyenangkan untuk anak-anak karena melibatkan pengeleman pada sesuatu yang mereka sukai. (Moeslichaton, 2004). Saat bermain kolase, anak sering menjumpai hal-hal yang dipenuhi dengan suasana yang menggembirakan. Biasanya kegembiraan ini ditandai dengan ciri-ciri seperti kebebasan bereksperimen, aktivitas, gerak, komunikasi, kompetisi, dan lain sebagainya. Kolase media merupakan kegiatan berbasis keterampilan, kegiatan yang sangat mudah dilakukan, dan kegiatan yang sangat digemari banyak anak. Agar anak tidak mudah bosan.

Berdasarkan observasi dari penelitian pendahuluan penulis, kemampuan motorik halus anak masih berada pada tingkat yang rendah. Anak-anak masih kurang mahir menggunakan jari mereka dalam tindakan yang agak rumit, dan mereka juga kurang konsentrasi, presisi, kesabaran, dan ketelitian dalam tugas-tugas motorik halus, terutama ketika mereka fokus pada objek yang lebih kecil. Nah, untuk mempelajari bagaimana perkembangan keterampilan motorik halus pada anak usia 5-6 tahun dengan menggunakan kolase, pada penelitian kali ini peneliti akan mempresentasikan hasil studi kolase untuk pengembangan keterampilan motorik pada anak usia 5-6 tahun di TK. Dharmawanita Persatuan Desaangun. Reggio, Kecamatan Ketapang, Lampung Selatan.

\section{METODE PENELITIAN}

Metode penelitian adala sebuah proses kerja untuk mengumpulkan data yang nantinya akan diolah agar menghasilkan data yang dapat memecahkan sebuah permasalah an penelitian. Metode penelitian yang digunakan dalam penelitian ini adalah metode analisis deskriptif dengan pendekatan kualitatif (Burhan Bungin, 2015). Penelitian ini memiliki tujuan supaya mendapatkan gambaran mengenai data yang akurat, fakta dengan apa adanya (Sugiyono, 2016). Sedangkan Suharsimi Arikunto menyatakan bahwa, jika penelitian bertujuan mengetahui tentang suatu keadaan tentang apa dan bagaimana, 
seberapa banyak, sejauh mana, maka penelitian nya bersifat deskriptif yaitu menjelaskan suatu kejadian (Arikunto, 2013). Adapun yang menjadi subyek penelitian ini adalah 1 orang tenaga pendidik/guru dan 17 anak didik di taman kanak-kanak Dharmawanita Desa Bangun Rejo Kecamatan Ketapang Lampung Selatan. Adapun penulis mengambil 1 orang sebagai subyek/sumber data karena peneliti menganggap mereka lebih menguasai dan memahami tentang obyek akan diteliti.

Dalam prosedur pengumpulan data yang ada dalam penelitian ini, peneliti melakukan pengumpulan data dengan menggunakan observasi, wawancara dan dokumentasi. Observasi biasa diartikan sebagai pengamatan atau pencatatan secara sistematik terhadap permasalahan yang ada pada objek penelitian. Adapun yang akan diobservasi dalam penelitian ini adalah anak usia 5-6 tahun dan juga 1 orang pendidik kelasnya. Dalam rangka menjalankan observasi ini, peneliti mencata semua hal yang dianggap perlu dan terjadi pada saat pelaksanaan berlangsung. Nantinya, lembar observasi yang digunakan saat mencatat pada pelaksanaan berlangsung akan dijadikan pedoman agar dapat melaksanakan observasi yang terarah. Wawancara merupakan tanya jawab yang dilakukan oleh dua orang dengan bertukan informasi-informasi yang dicari, nantinya hasil wawancara ini akan diolah untuk mendapatkan makna dalam suatu topik wawancara yang dilakukan. Dokumentasi adalah sebuah kumpulan catatan yang diperlukan oleh peneliti, contohnya foto, video dan berupa berkas atau file-file RPPH, visi misi sekolah yang dibutuhkan oleh peneliti sebagai catatan pendukung penelitian.

Prosedur analisis data yang dipakai oleh peneliti yaitu reduksi data, display data dan verifikasi. Reduksi data ialah sebuah rangkuman dari hasil observasi dan wawancara untuk mempermudah peneliti dalam memfokuskan data. Nantinya data yang tidak termasuk dalam penelitian tidak akan disajikan lebih jauh dalam penelitian. Display data ialah penyajian data dalam bentuk teks naratif yang menggambarkan dengan jelas hasil penelitian yang telah dilakukan dan mudah dipahami sebagai informasi penelitian. Verifikasi ialah penarikan kesimpulan, dalam verifikasi data yang dibutuhkan, penulis mengumpulkan data dengan mereduksi dan mendisplay data yang nantinya akan diverifikasi dnegan mencocokkan teori-teori yang terkait pada penggunaan media kolase dalam mengembangkan keterampilan motoric halus anak usia 5-6 tahun 


\section{HASIL PENELITIAN DAN PEMBAHASAN}

Dari hasil pengatan dan wawancara yang dilakukan oleh penulis terhadap guru kelas B1 TK Dharmawanita, di wilayah Ketapang-Lampung Selatan, dapat dikatakan bahwasanya pengembangan keterampilan motorik halus anak usia 5-6 tahun ada yang belum berkembang. Ini bisa dilihat dalam kegiatan koordinasi antara mata dan tangan. Pada saat penelitian dilakukan, guru terlihat melakukan beberapa perubahan, sehingga perkembangan keterampilan anak dapat menjadi lebih baik lagi. Jadi peneliti dapat disimpulkan bahwasanya, dalam sebuah pembelajaran guru sudah menyiapkan bahan yang akan digunakan. Berikut adalah pembahasan dan analisis data selanjutnya sebagai langkah untuk mengambil kesimpulan. Dari 17 peserta didik di TK Dharmawanita Persatuan, dalam kegiatan pembelajaran terdapat 4 anak yang termasuk aktif, memiliki keterampilan motorik halus yang baik. Sedangkan, yang memiliki keterampilan motorik halus yang cukup terdapat 9 peserta didik. Lalu, terdapat 7 anak yang memiliki perkembangan keterampilan motorik halus belum berkembang dan masih memerlukan perkembangan yang diharapkan oleh para guru.

Berdasarkan hasil deskripsi observasi dan wawancara yang dilakukan oleh peneliti TC Darmavanita: (1) guru merencanakan gambar yang dibuat sesuai dengan topik, dimana guru terlebih dahulu menganalisis kurikulum sesuai dengan ketentuan kurikulum 13 dan menentukan topik serta menentukan topik. Program pelatihan disajikan dalam bentuk RPPH, RPPM dan perencanaan semester. Tema disajikan "tentang diri Anda", dengan beberapa opsi gambar, seperti bingkai, tangan, es krim, dan anggur; (2) Guru menyiapkan alat dan bahan yang akan digunakan untuk merekatkan. Dari hasil observasi dan wawancara yang diberikan di atas dapat disimpulkan bahwa seorang guru TK Dharmawanita Persatuan Bangun Rejo, Kecamatan Ketapang, Lampung Selatan menyiapkan alat dan bahan yang diperlukan untuk pengembangan keterampilan motorik pada anak usia 5 sampai 6 tahun di TK Dharmawanita kelas B1. Persatuan; (3) Guru menjelaskan dan menyajikan alat dan bahan yang digunakan untuk memperkuat keterampilan dan cara menggunakannya. Dari observasi yang dilakukan di TK Dharmavanita Persatuan Desa Bangun Rejo Kecamatan Ketapang, Lampung Selatan, penulis menyimpulkan bahwa guru menjelaskan dan menyajikan alat dan bahan yang akan digunakan sebelum memulai kolase; (4) Guru menjelaskan kapan penerapan yang benar sesuai dengan bentuk gambar, dan memperlihatkannya sehingga hasil gambar tidak sesuai, 
berdasarkan observasi dan wawancara di TK Dharmawanita Persatuan Desa Bangun Rejo, Ketapang, Lampung Selatan, penulis Dapat disimpulkan bahwa dengan melakukan tugas kolase untuk anak-anak dalam proses kegiatan, jelas guru sebelumnya. Hal ini dilakukan agar Anda dapat dengan mudah melakukan pembelajaran tentang perkembangan motorik halus pada anak sambil nempel; (5) Guru membimbing anak melalui proses attachment untuk foto wawancara dan observasi di TK Dharmawanita Persatuan Desa Bangun Rejo, Kecamatan Ketapang, Lampung Selatan. Penulis dapat menyimpulkan bahwa guru selalu memotivasi anak agar dapat bertindak dengan benar dan benar; (6) Guru mengevaluasi pekerjaan kelulusan anak.

Dari hasil pengamatan dan wawancara yang dilakukan, dapat peneliti simpulkan bahwasanya guru di TK Dharmawanita telah mengembangkan keterampilan motorik halus pada anak usia 5-6 tahun di kelas B1 menggunakan media kolase dalam kegiatan menempel, menirukan bentuk, dapat memakai alat tulis dengan benar. Membuat kolase dari gambar foto aku, tangan, es krim, dan anggur yang dibuat dengan benar sesuai pendapat para ahli dan Menteri Pendidikan nasional Republik Indonesia.

\section{SIMPULAN DAN SARAN}

Berdasarkan hasil analisis dan pembahasan sebelumnya, penulis dapat menyimpul kan bahwa pengembangan keterampilan motorik halus pada anak usia 5 hingga 6 tahun menggunakan kolase di TK Dharmawanita Persatuan dilakukan sesuai dengan prosedur, yaitu rencanakan gambar, siapkan alat dan bahan untuk perekatan, menjelaskan dan perkenalkan alat dan bahan untuk perekatan dan bagaimana caranya, menjelaskan cara menempel yang benar sesuai dengan bentuk gambar dan mendemonstrasikannya sehingga hasilnya tidak melampaui garis, membimbing anak-anak dalam proses menempelkan bahan yang disediakan untuk gambar dan mengevaluasi pekerjaan anak. Sementara itu, dalam pelaksanaan kegiatan menempel, penilaian pekerjaan anak tidak dilakukan oleh guru, oleh karena itu dampaknya belum maksimal. Berdasarkan hasil penelitian mengembangkan keterampilan motorik halus pada anak usia 5 hingga 6 tahun menggunakan kolase di TK Dharmawanita Persatuan, penulis dapat membuat saran dan diharapkan akan dipertimbangkan oleh beberapa pihak, termasuk: (1) Untuk kepala TK Dharmawanita Persatuan : Direkomendasikan untuk menerbitkan pengasuh yang lebih disiplin sehingga mereka dapat berangkat lebih awal serta mendisiplinkan pendidik serta 
wali murid mengenai jam sekolah siswa agar tidak gegabah atau meremehkan jam sekolah,

(2) Untuk pendidik; Disarankan agar menyusun lembar penilaian pada semua aspek perkembangan anak untuk mengetahui tingkat perkembangan siswa dan mengevaluasinya lagi.

\section{DAFTAR PUSTAKA}

Ahmad Susanto. (2015). Bimbingan dan Konseling di Taman Kanak-kanak. Prenada Media Group.

Altenmüller, E. (2003). Focal dystonia: Advances in brain imaging and understanding of fine motor control in musicians. Hand Clinics, 19(3), 523-538. https://doi.org/10.1016/S07490712(03)00043-X

Arif S. Sadirman dkk. (1984). Media Pendidikan: Pengertian, Perkembangan dan Pemanfaatannya. Jakarta : Raja Grfindo Persada.

Arikunto, S. (2013). Prosedur Penelitian: Suatu Pendekatan Praktik. Edisi Revisi V Rinika Cipta : Jakarta.

Ayu Husniyatul Laily. (2014). Meningkatkan Kemampuan Motorik Halus Melalui Kegiatan Menggunting Dengan Metode Demonstrasi Pada Anak Usia 5-6 Tahun Di TK Putra Harapan Jatipelem Dowek Jombang. $\quad 1(2), \quad 9$. https://doi.org/https://jurnalmahasiswa.unesa.ac.id/index.php/paud-teratai/article/view/8267

Azizah, A. N. (2017). Upaya Meningkatkan Hasil Belajar Siswa Melalui Model Pembelajaran Project Based Learning (Penelitian Tindakan Kelas Pada Tema Lingkungan Sahabat Kita Subtema Usaha Pelestarian Lingkungan di Kelas V SDN Pameungpeuk 1 Kecamatan Pameungpek Kabupaten Bandung). 5. http://repository.unpas.ac.id/30802/.

Bambang Sujiono, dkk. (2012). Metode Pengembangan Fisik. Tanggerang Selatan : Universitas Terbuka.

Burhan Bungin. (2015). Metodologi Penelitian Kualitatif. Jakarta : Rajawali Pers.

Cllaudia, E. S., Wdiastuti, A. A., \& Kurniawan, M. (2018). Origami Game for Improving Fine Motor Skills for Children 4-5 Years Old in Gang Buaya Village in Salatiga. Jurnal Obsesi : Jurnal Pendidikan Anak Usia Dini, 2(2), 143. https://doi.org/10.31004/obsesi.v2i2.97

Depdikbud. (2013). Permendikbud Nomor 66 Tahun 2013 tentang Standar Penilaian. In Jakarta: Departemen Pendidikan dan Kebudayaan. Jakarta: Departemen Pendidikan dan Kebudayaan.

Effi Kumala sari. (2018). Peningkatan Perkembangan Motorik Halus Anak Melalui Kegiatan Kolase Dari Bahan Bekas Di Taman Kanak-kanak Aisyiah. 51(1), 51. https://doi.org/https://doi.org/10.24036/1615

Indraswari, L. (2012). Peningkatan Perkembangan Motorik Halus Anak Usia Dini Melalaui Kegiatan Mozaik Di Taman Kanak-Kanak Pembina Agam. Jurnal Pesona PAUD, 1(1-13), 1-13. https://doi.org/https://doi.org/10.24036/1633

Kartikasari, A. (2013). Meningkatkan kemampuan motorik halus anak usia 5-6 tahun melalui kegiatan mewarnai gambar di TK al-iqra' mataram tahun ajaran 2012/2013. Jurnal PAUD, $1(1)$.

Mary Mayesky. (2011). Aktivitas-Aktivitas Seni Kreatif. Jakarta Barat:Indeks.

Misiyanti, N. W., Parmiti, D. P., \& Wirya, I. N. (2018). Penerapan metode demonstrasi berbantuan media konkret melalui kegiatan kolase untuk meninkatkan perkembangan motorik halus. $E$ Journal PG-PAUD, 2(1), 1-11. https://doi.org/http://dx.doi.org/10.23887/paud.v2i1.2984

Moeslichaton. (2004). Metode Pengajaran di Taman Kanak-Kanak. Jakarta: Rineka Cipta.

Mulyasa, E. (2014). Manajemen PAUD. Rosda Karya. 
Nana Sudjana. (2016). Penilaian Hasil Proses Belajar Mengajar. Bandung : Rosdikarya.

Paizaluddin, E. (2016). Penelitian Tindakan Kelas (Classroom Action Research) Panduan Teoritis dan Praktis. Bandung : Alfabeta.

Pura, D. N. (2019). Perkembangan Motorik Halus Anak Usia Dini Melalui Kolase Media Serutan $\begin{array}{llll}\text { Pensil. Jurnal Ilmiah } & \text { Potensia, }\end{array}$ https://doi.org/https://doi.org/10.33369/jip.4.2.131-140

Ramdhania, A. \& T. (2012). Assiikkk Bermain dan Berkreasi. Yogyakarta : Pustaka Grahatama.

Romlah. (2017). Pengaruh motorik Halus dan motorik kasar terhadap perkembangan kreativitas anak usia dini. Jurnal Ilmu Tarbiyah Dan Keguruan, 22(2), 12.

Rully ramdansyah. (2010). Pengembangan Kreativitas Seni Rupa Anak Sekolah Dasar. Jakarta: Depdiknas.

Sugiyono. (2016). Metode Penelitian Kuantitatif, Kualitatif, dan R\&D. Bandung : Alfabeta.

Sumanto. (2006). Perkembangan Kreativitas Seni Rupa Anak TK. Jakarta: Depdinas.

Sumantri. (2005). Model Pengembangan Keterampilan Motorik Anak Usia Dini. Jakarta: Departemen Pendidikan Nasional. Direktorat Jenderal Pendidikan Tinggi. Direktorat Pembinaan Pendidikan Tenaga Kependidikan Dan Ketenagaan Perguruan Tinggi.

Suyadi. (2010). Psikologi Belajar PAUD, Pedagogia.

Syakir Muharrar dan Sri Verayanti. (2013). ) Kolase, Montase dan Mozaik. In Jakarta: Erlangga. Uyu Wahyudin dan Mubiar Agustin. (2001). Penilaian Perkembangan Anak Usia Dini (R. Aditama (ed.)). Bandung: Refika Aditama.

Wandi, Z. N., \& Mayar, F. (2019). Analisis Kemampuan Motorik Halus dan Kreativitas pada Anak Usia Dini melalui Kegiatan Kolase. Jurnal Obsesi : Jurnal Pendidikan Anak Usia Dini, 4(1), 363. https://doi.org/10.31004/obsesi.v4i1.347

Wulandari, K. (2015). Hubungan Lagu dengan Pengembangan Kemmapuan Matematika Awal Anak Usia 4-5 Tahun. Diss. Fakultas Keguruan Dan Ilmu Pendidikan. https://doi.org/http://repository.radenintan.ac.id/4574/1/SKRIPSI\%20\%20TARI.pdf

Yuliani Nuraini Sujiono. (2013). Konsep Dasar Anak Usia Dini. Jakarta : PT Indeks.

Yutika Oktavia Ardila. (2017). Penggunaan Media Kolase Dalam mengembangkan Keterampilan Motorik Halus Anak Usia Dini Di Taman Kanak-kanak Citra Darma Lampung Barat. Universitas Islam Negeri Raden Intan Lampung. https://doi.org/http://repository.radenintan.ac.id/id/eprint/1314 